DOI: https://doi.org/10.15407/techned2018.05 $: 031$

\title{
RESEARCH OF A BI-DIRECTIONAL DC-DC CONVERTER OF UNIFIED INVERTER MODULE FOR APPLICATION IN ENERGY ACCUMULATION SYSTEMS
}

Journal

Publisher

ISSN

Issue

Pages
Tekhnichna elektrodynamika

Institute of Electrodynamics National Academy of Science of Ukraine 1607-7970 (print), 2218-1903 (online)

No 5, 2018 (September/October)

$31-34$

\section{Authors}
A.F. Zharkin ${ }^{\star}$, A.G. Pazieiev ${ }^{\star \star}$, V.A. Novskyi ${ }^{\star \star \star}$
Institute of Electrodynamics National Academy of Sciences of Ukraine,
pr. Peremohy, 56, Kyiv, 03057, Ukraine,
e-mail: pazeev@ied.org.ua
* ORCID ID : http://orcid.org/0000-0001-5996-0901
** ORCID ID : http://orcid.org/0000-0003-1944-4114
*** ORCID ID : http://orcid.org/0000-0003-3857-7027

The results of the simulation modeling of a bidirectional dc-dc converter, which is part of the unified inverter module of multimodal systems of accumulation of electric power utilization, are presented, and the influence of the basic parameters and operating modes of the converter on the value of the currents of the power elements is investigated. The maximum values of currents and voltages in a $300 \mathrm{~kW}$ power converter are obtained, which provides the possibility of a reasonable choice of power switching elements, engineering calculations and the choice of power reactive elements and control system parameters. References 7 , figures 5. 
Key words: systems for the accumulation of electricity, bi-directional dc-dc converter, bi-directional inverter module, IGBT- module.

Received: 05.03.2018

Accepted: 21.03.2018

Published: 16.08 .2018

\section{References}

1. Smolentsev N.I. Power storage in local electrical networks. Polzunovskiy vestnik. 2013. No 4-2. Pp. 176-181. (Rus)

2. Bright prospects. ABB Magazine. Energy of the mind. 2017. No 1. Pp. 4-17. Available at: http://new.abb.com/docs/librariesprovider55/Пресca-о-нас/абб-энергия-разума-01-2017.pdf? $\underline{\text { sfvrsn=2 }}$

. (Rus)

3. Naayagi R.T., Forsyth A.J. and Shuttleworth R. High-Power Bidirectional DC-DC Converter for Aerospace Applications. IEEE Transactions on Power Electronics. 2012. Vol. 27. No 11. Pp. 4366-4379. DOI:

s://doi.org/10.1109/TPEL.2012.2184771

4. Martynov V.V., Rudenko Yu.V. Specialized power supply systems for electro-technological equipment. Tekhnichna Elektrodynamika. 2012. No 3. Pp. 101-102. (Rus)

5. Zhang J., Lai J.-S., Kim R.-Y. and Yu W. High-power density design of a soft-switching high-power bidirectional DC-DC converter. IEEE Transactions on Power Electronics. 2007. Vol. 22. Issue 4. Pp. 1145-1153.

6. Zharkin A.F., Pazieiev A.H., Novskyi V.O., Malakhatka D.O. The quality of the output voltage three-phase active power factor correction. Visnyk NTU KHPI. Zbirnyk naukovykh prats. 2017. No 27 (1249). Pp. 354-359. (Rus)

7. Shydlovskyi A.K., Zharkin A.F., Pazieiev A.H. Continuous approximate model of AC/DC converters with active power factor correction. Tekhnichna Elektrodynamika. 2011. No 6. Pp. 11-17. (Ukr) 
2018 n 5 s 6

\section{PDF}

